The Cryosphere Discuss., 5, 401-430, 2011

www.the-cryosphere-discuss.net/5/401/2011/

doi:10.5194/tcd-5-401-2011

(C) Author(s) 2011. CC Attribution 3.0 License.

\title{
Glacial debris cover and melt water production for glaciers in the Altay, Russia
}

\section{Mayer ${ }^{1}$, A. Lambrecht ${ }^{2}$, W. Hagg ${ }^{3}$, and Y. Narozhny ${ }^{4}$}

${ }^{1}$ Commission for Glaciology, Bavarian Academy of Sciences and Humanities, Alfons-Goppel Str. 11, 80539 Munich, Germany

${ }^{2}$ Institute of Meteorology and Geophysics, University of Innsbruck, Innrain 52, 6020 Innsbruck, Austria

${ }^{3}$ Geography Department, Ludwig-Maximilians-University, Luisenstr. 37, 80333 Munich, Germany

${ }^{4}$ Glacial Climatology Laboratory, Tomsk State University, Tomsk, Russia

Received: 9 January 2011 - Accepted: 13 January 2011 - Published: 1 February 2011

Correspondence to: C. Mayer (christoph.mayer@Irz.badw-muenchen.de)

Published by Copernicus Publications on behalf of the European Geosciences Union.

Glacial debris cover and melt water production for glaciers

C. Mayer et al.

\section{Title Page}

Abstract

Conclusions

Tables

14

4

Back

Full Screen / Esc

Printer-friendly Version

Interactive Discussion 


\section{Abstract}

Glaciers are important water storages on a seasonal and long-term time scale. Where high mountains are surrounded by arid lowlands, glacier runoff is an important source of water during the growing season. This situation can be found in the Altay mountains

5 in Southern Siberia, where the recent glacierization of $>700 \mathrm{~km}^{2}$ is subject to continuous mass loss, even though the shrinking is comparably slow. The glacier retreat is accompanied by an extension of supra-glacial moraine, which itself strongly influences ablation rates.

To quantify these effects, the spatial evolution of debris cover since 1952 was analysed for three glaciers in the North Chuya Ridge using satellite and airborne imagery.

In summer 2007, an ablation experiment was carried out on debris covered parts of Maliy Aktru glacier. Thermistors in different depths within the moraine provided data to calculate thermal resistance of the debris. A set of ablation stakes was installed at locations with differing debris thickness and observed regularly throughout the entire 15 melt season. Air temperature from an AWS was used to calculate degree day factors in dependence of the debris thickness. To take into account the shading effect of surrounding walls and peaks, the potential solar radiation and its evolution throughout the summer was determined from a digital elevation model. This allows us to extrapolate our measurements from Maliy Aktru to the other two glaciers of the Aktru basin and to estimate basin melt rates. In addition accumulated ice melt was derived for 12 glaciers in the North Chuya Range. Changes in summer runoff from the 1960 s are compared to the results from our melt model and the evolution of debris cover is analysed in respect to the melt activity.

\section{Introduction}

25 Debris covered glaciers (DGC) are a common glacier type, especially in the arid regions of Central Asia and the Hindukush-Himalaya range (Moribayashi and Higuchi, 1977). But also in other regions morainic deposits on glaciers are common and occur

Glacial debris cover and melt water production for glaciers

C. Mayer et al.

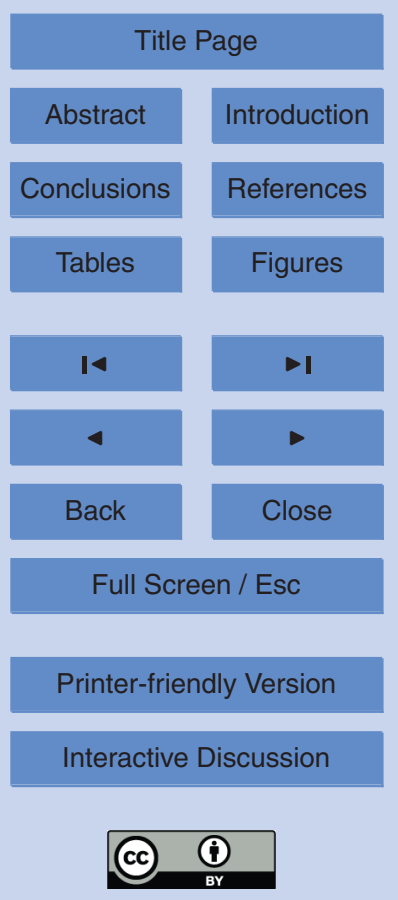


in a wide range, from completely debris covered tongues (e.g. Miage glacier in the Italian Alps, Smiraglia et al., 2000) to only small areas of fine dust and small stones as can be observed on many Alpine glaciers.

Debris covers have a profound impact on the melt water generation on glaciers (Ad5 hikari et al., 2000). Depending on the thickness of the debris, they either intensify ice melt (for a thin debris layer), or reduce melting due to forming a protective layer on top of the ice (e.g. Østrem, 1959). Therefore it is essential to determine the extent, the thickness and also the thermal properties of a supra-glacial debris cover, in order to derive realistic ablation rates. Long periods of negative glacier mass balances will 10 increase the extent of debris cover on glaciers. Reduced ice velocities, at least in the lower parts of the ablation zone, accumulate supraglacial morainic material in these regions. Also the strong melt rates will increase the accumulation of englacial debris on the glacier surface. Such an accumulation of debris over extended time periods consequently leads to a protection of glacier ice from solar radiation and thus reduces 15 the local melt rates.

The glacier cover in the Russian Altay is about $748 \mathrm{~km}^{2}$ (Narozhny et al., 2009), divided into three main areas: the North Chuya $\left(155 \mathrm{~km}^{2}\right)$ and the South Chuya $\left(202 \mathrm{~km}^{2}\right)$ Ranges as well as the Katun Range $\left(298 \mathrm{~km}^{2}\right.$ ) around Belukha Peak (4506 m a.s.I.), the highest peak of the mountain system. In this part of the Altay, debris covered glaciers are not very widespread yet. However, several glaciers exhibit debris covered tongues and extended supraglacial moraine ridges. Also a thin debris cover can be observed over large altitude ranges on some glaciers. In this study we investigate the temporal evolution of the debris cover in a representative region by the analysis of remote sensing imagery. The influence of the debris cover on the melt water production from these glaciers is simulated by a melt model based on the degree day approach.

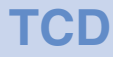

$5,401-430,2011$

Glacial debris cover and melt water production for glaciers

C. Mayer et al.

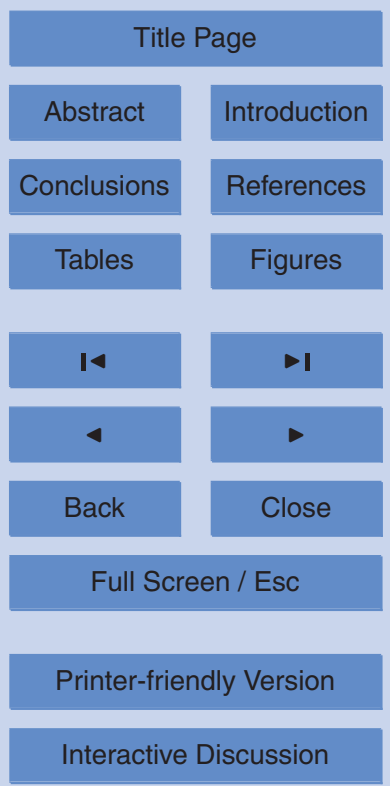




\section{Study area and data compilation}

The test area is situated in the North Chuya Range, centered around the Aktru drainage basin (approx. 50 $04^{\prime} \mathrm{N}, 87^{\circ} 46^{\prime} \mathrm{E}$ ) and includes twelve glaciers (Fig. 1, Table 1). In this area the mountains reach up to $4000 \mathrm{~m}$ in elevation and are widely glacier covered.

5 The largest glaciers in the investigated area, Jelo and Leviy Karagemsky both cover about $7 \mathrm{~km}^{2}$ in area, while the largest of the Aktru glaciers, Leviy Aktru provides an area of almost $6 \mathrm{~km}^{2}$. Melt water is directed to the North via the Chuya river into the Katun river, the main tributary of river Ob. South of the divide the water flows into the Chuya river via Taltura and Chaga Uzun in the eastern part and directly into the Katun river via

10 Karagem and Argum rivers in the western part. In general the glacier tongues reach down to about $2200 \mathrm{~m}$ to $2300 \mathrm{~m}$ a.s.l., where most of the lowest parts are covered by debris to a varying degree.

Climate information is derived mainly from data of the weather station in Kosh Agach $\left(50^{\circ} 01^{\prime} \mathrm{N}, 88^{\circ} 41^{\prime} \mathrm{E}\right)$, about $65 \mathrm{~km}$ to the East of our region at $1760 \mathrm{~m}$ elevation. This 15 is the nearest meteorological station with long term observations available. From this station monthly data of temperature and precipitation are available from 1938 until 2003 and daily observations cover the period from 2000 until 2003. The daily values were used for calculating the air temperature for the individual elevation bands of the glacier distribution, using a lapse rate of $0.007^{\circ} \mathrm{C} / \mathrm{m}$. In addition, data are also available from the Aktru meteorological station on a less continuous basis. This station is situated northeast of, and close to the Aktru glaciers in about $2140 \mathrm{~m}$ elevation. The mean annual precipitation at this station is about $540 \mathrm{~mm}$. While more than $80 \%$ of this amount is accumulated during the months April to October, the stable Siberian High prevents strong precipitation events during the winter season (Surazakhov et al., 2007).

The analysis of the glacier and debris evolution over time is mainly based on remote sensing imagery, covering a time period of more than 50 years from 1952 until 2008. Details about the used images can be found in Table 2 .

\section{Glacial debris cover and melt water production for glaciers \\ C. Mayer et al.}

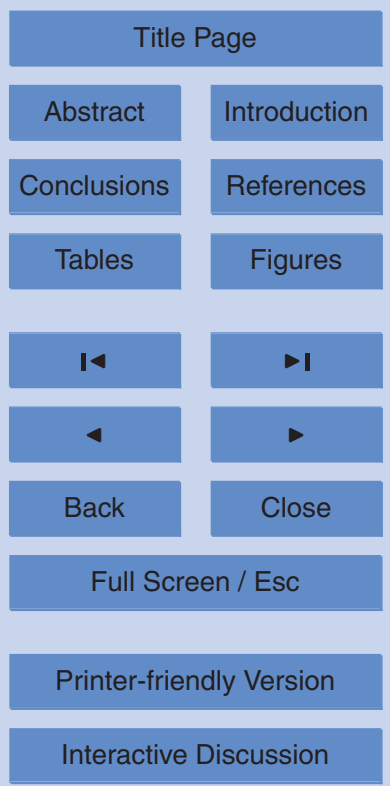


During the ablation season 2007 detailed field investigations were carried out on Maliy Aktru glacier, focusing on ice ablation from the debris covered areas of the glacier. Also temperature gradients were measured within the debris cover at ablation measurement locations, in order to obtain information about the thermal properties of 5 the debris material in this region. For the Aktru drainage basin monthly runoff data are available for the summer months of some years in the 1960s and 1970s. These data are used to evaluate the impact of the debris cover on the melt water contribution to summer run-off.

\section{Analysis of glacier and debris cover evolution}

10 A Spot image from 2008 was used as reference image for the analysis of surface type and surface area changes (see Table 2 for image details). For this purpose, the image was orthorectified using the SRTM-3 digital elevation model as source of the relief (Jarvis et al., 2008). All other images were then co-registered onto the Spotorthoimage, using the geometric correction tool of ERDAS Imagine and temporally 15 stable surface features as tie points. Because only relative changes in debris cover and glacier area are determined, there is no need for a highly accurate absolute location of the images, as long as the co-rectification is sufficient for change detection. According to Surazakhov et al. (2007) a potential error for the 1952 aerial imagery of up to $1.7 \mathrm{~m}$ is introduced by scanning problems of the paper prints. For the Corona $\mathrm{KH}-7$ image 20 the scan resolution $(1.2 \mathrm{~m})$ is well below the photographic resolution $(4 \mathrm{~m})$, so that no additional errors are introduced during digitizing. Still, the wide-angle geometry of the Corona image required a large number of tie points to produce a satisfactory co-rectification which is below the pixel accuracy of the reference Spot image. The combination of Landsat images from 2000 and 2008 improved the accuracy of corectification, because the glacier conditions of 2008 were identical to the situation in the Spot scene. Despite the comparably low resolution of the multispectral Landsat scenes, the glacier boundary delineation fitted well into the general pattern of the higher resolution images.

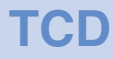

5, 401-430, 2011

Glacial debris cover and melt water production for glaciers

C. Mayer et al.

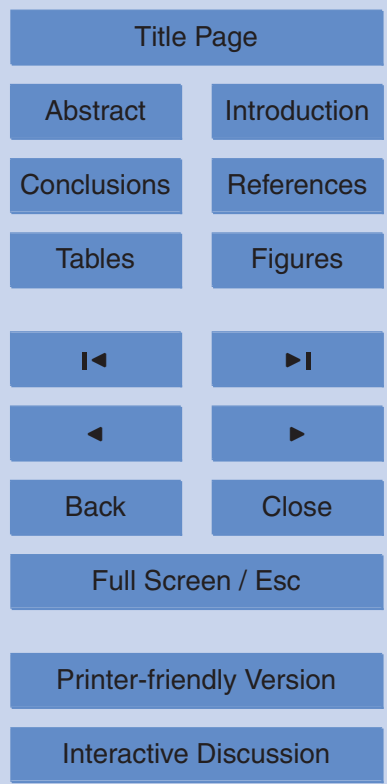


The delineation of glacier boundaries and debris cover extent was then carried out on the corrected images, but with their original spatial resolution, in order to obtain the highest possible accuracy. Especially for the debris covered parts of the glaciers, glacier margin delineation is rather difficult and requires experience. For the clean ice 5 and firn parts the glacier boundaries were defined by the brightness contrast in respect to adjacent rock areas and the catchment boundaries derived from the digital elevation model. For the debris covered areas, boundaries could be identified based on local information from the field visit on the 2008 images. In all images used for the analysis, the debris covered glacier tongues show clear break lines at the termini. Also the

10 transition from the debris covered glacier surface to the adjacent moraines could be clearly delineated due to the change in surface slope. Ice cored moraines however, cannot be identified by optical inspection of the surface and are therefore not included in the glacier area. The accuracy of the glacier boundary delineation is within one pixel size for the transition from ice to rock and about 1-2 pixels in the other cases. Figure 2 shows an example of the delineation of glacier boundaries and debris cover for the Aktru glacier tongues.

\subsection{Results of the glacier change analysis}

The results of the analysis of debris cover evolution for all glaciers are documented in Fig. 3. In general, the 12 glaciers in the area of investigation lost about $6.9 \%$ of 20 their area during 42 years between the first Corona image and the latest Spot image. This is in very good agreement with earlier investigations (Surazakhov et al., 2007). This reduction in glacier area is considerably smaller than it was observed in other mountain areas of the world (Lambrecht and Kuhn, 2007; Narozhny et al., 2006; Paul et al., 2004), including most mountain ranges of Central Asia (e.g. Tien Shan: Bolch, 25 2007; Aizen et al., 2007, central Tibet: Yang et al., 2003, Pamir for an earlier period: Shetinnikov, 1998).

During the same time period, the debris cover increased from $9.3 \%$ to $12.3 \%$ (see also Table 1). The absolute area of debris covered ice increased by $1.3 \mathrm{~km}^{2}$, while 406

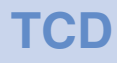

$5,401-430,2011$

Glacial debris cover and melt water production for glaciers

C. Mayer et al.

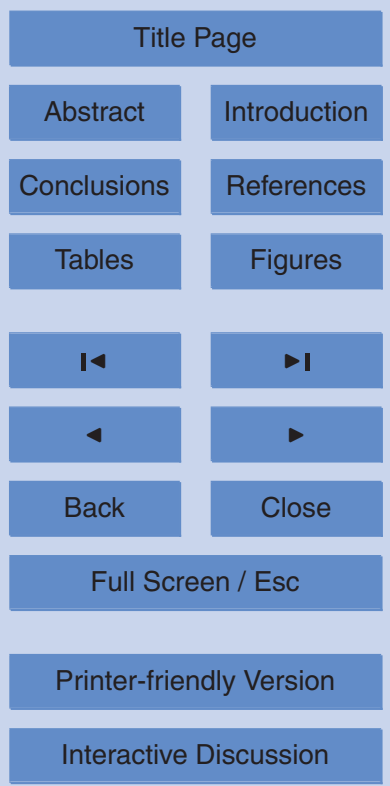

Interactive Discussion 
the total glacier area of the sample glaciers decreased by $3.9 \mathrm{~km}^{2}$ between 1966 and 2008. The possible error for glacier and debris cover delineation results in about $4-5 \%$ for the area calculations. Therefore the determined changes $(6.5 \%$ for the glacier area reduction and $23.3 \%$ for the debris cover change) are well above the error margin.

5 The distribution of the debris cover with altitude in Fig. 4 shows that in general the lower parts of the glaciers are partially debris covered with values between 30 and $70 \%$. Between $2500 \mathrm{~m}$ and $2750 \mathrm{~m}$ the debris cover typically is above $50 \%$, while it continually reduces with higher elevations, reaching very low values above $3300 \mathrm{~m}$, approximately the mean equilibrium line altitude of the region.

\section{Field measurements of debris covered ablation}

Debris cover mapping is possible on the basis of high resolution satellite imagery. For determining the influence of the debris cover on glacier melt, it is still necessary to investigate the local conditions in respect to the thermal properties of the debris cover. A field experiment focused on this task was carried out during the summer 2007. As 15 sample glacier, Maliy Aktru was chosen, because it is partially covered by debris and there exists a long-term mass balance series for this glacier since 1961 (Haeberli et al., 2007). Maliy Aktru glacier has a wide accumulation basin ranging from $3160 \mathrm{~m}$ to $3700 \mathrm{~m}$ in elevation. The glacier tongue is rather narrow and steep, reaching down to $2250 \mathrm{~m}$ at a general exposition of $\mathrm{N}$. The lowermost part of the tongue is completely covered by a rather thin layer of fine grained debris. In addition, a narrow debris band stretches from a small plateau at about $2600 \mathrm{~m}$ down to the glacier snout on the right part of the glacier. Also some parts of the left glacier margin are debris covered, but these areas could not be investigated due to frequent rock fall.

Across the debris covered parts of the glacier an array of 11 stakes was installed at 2511 July, designed to cover the entire variability of debris thicknesses observed (Fig. 1). The length of the stakes was between two and six meters, depending on the estimated amount of melt during the ablation season. For determining the thermal properties of

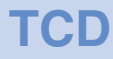

$5,401-430,2011$

Glacial debris cover and melt water production for glaciers

C. Mayer et al.

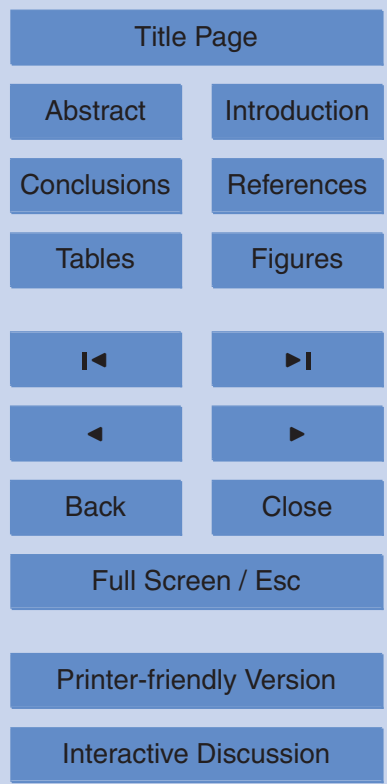

Interactive Discussion 
the supra-glacial debris three thermistors were installed in the debris cover of an ice cored moraine at the margin of the glacier tongue to monitor the vertical temperature gradient during the ablation experiment.

Ice melt at the stakes was measured frequently for a period of 19 days and then 5 the observations continued on a non-regular basis for the rest of the ablation season. From these measurements a relation between the daily mean air temperature and the sub-debris ice melt could be established. This method, usually used for determining the ablation on clean glaciers (e.g. Braithwaite, 1995) also works for debris covered glaciers (Mihalcea et al., 2006). Although the scatter of the resulting melt rates is 10 larger due to variations in debris conditions and glacier exposition.

\subsection{Results from the ablation experiment}

The degree day factor and thus the amount of melt for a given mean air temperature was calculated for the individual stake locations. All the results together provide information about sub-debris ice melt in dependence of debris thickness (Fig. 5), given that 15 debris thickness is the governing variable and other parameters like lithology and grain size do not change too much. The measurement at $1 \mathrm{~cm}$ debris thickness in Fig. 5 was influenced by a change of the debris cover during the period of observations and therefore is excluded from this analysis. Glacier melt is stronger for a very thin debris cover, compared to clean ice melt, and reaches a maximum at about $0.9 \mathrm{~cm}$ for Maliy Aktru 20 glacier as can be deduced from longer term measurements and other investigations (e.g. Mihalcea et al., 2006; Konovalov, 2000). After the maximum, melt rates decrease again and reach the same magnitude as for clean ice at the critical debris thickness of about $2 \mathrm{~cm}$. For a further increase in debris thickness the melt rates decrease rapidly reaching about $50 \%$ of the clean ice value at $10 \mathrm{~cm}$, while a debris thickness of 20 $25 \mathrm{~cm}$ results in barely $15 \%$ ice melt compared to the absence of supra-glacial debris. These results are similar to observations at, for example, Rakhiot Glacier (Mattson et al., 1993) and Khumbu Glacier (Kayashta et al., 2000), but show a somewhat faster decrease of melt rates for thicker debris covers. Compared to investigations in the

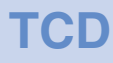

$5,401-430,2011$

Glacial debris cover and melt water production for glaciers

C. Mayer et al.

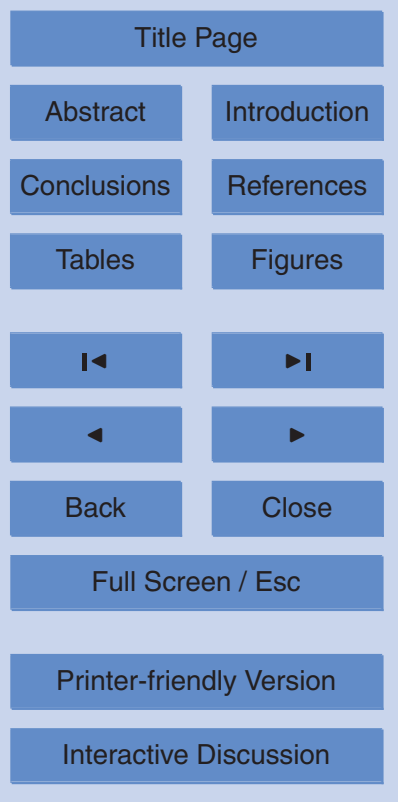

Interactive Discussion 
Caucasus, the shape of the ablation relation is similar, but the degree day factors for different debris thicknesses are considerably smaller at Maliy Aktru (Lambrecht et al., submitted). The steep slope of the melt rate function, after reaching the maximum melt at only a few centimeters of debris thickness and the asymptotic behavior above $510-15 \mathrm{~cm}$ of debris thickness is found in most field investigations (e.g. Mihalcea et al., 2006, Mayer et al., 2010). For the further analysis it is assumed that the influence of the debris thickness on the ice melt is the same for the other glaciers in the area, because the geological conditions, as well as the morphology and the altitudinal distribution of the glaciers are rather similar across the region.

\section{A degree day model for sub-debris ablation}

Measurements of sub-debris ice ablation and air temperature generally show a good correlation (e.g. Hagg et al., 2008) and therefore the ablation on debris covered glaciers can be estimated by using a similar approach as on clean glaciers. Simplified models exist since a long time (e.g. Nakawo and Takahashi, 1982), while also more physically 15 based models have been developed to calculate the energy transfer through the debris cover (Nicholson and Benn, 2006, Reid and Brock, 2010). For remote regions with a limited availability of meteorological data, however, a simple degree day approach is still a good choice for estimating bulk melt rates. Such models require at least information about the debris cover distribution and data about the relation between debris thickness and ice melt for given mean air temperatures. Both these basic input data exist for our region of interest. However, it should be noted that such a simple melt relation is only valid for a specific region (Nicholson and Benn, 2006). Within the model, the mean ablation a is calculated for $50 \mathrm{~m}$ elevation bands, using the degree day sum $\mathrm{D}_{s}$ at the respective altitude, derived from positive air temperatures during the ablation

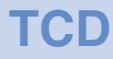

$5,401-430,2011$

Glacial debris cover and melt water production for glaciers

C. Mayer et al.

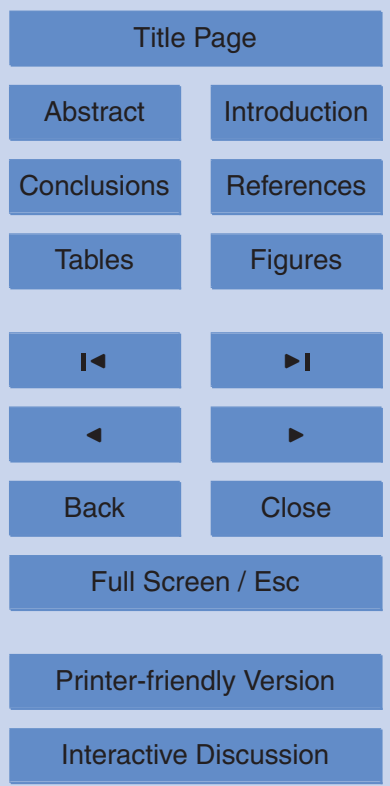


cover $\mathrm{A}_{d}$ and the mean debris thickness $\mathrm{h}$ is required:

$a=\frac{\left(\mathrm{A}-\mathrm{A}_{\mathrm{d}}\right)}{\mathrm{A}} \mathrm{D}_{s} d_{f}(i)+\frac{\mathrm{A}_{d}}{\mathrm{~A}} \mathrm{D}_{s} d_{d}(h)$.

The degree day factor for ice $d_{f}$ and the function of degree day factors for different debris thicknesses $d_{d}(h)$ are determined from the field measurements described above.

5 With this mean ablation rate, the total ablation for the entire ablation zone can be calculated by summing up the values for the individual elevation bands. Debris cover thickness was estimated for the glaciers in the region based on classification of remote sensing images, from the thickness measurements on Maliy Aktru glacier and observations on the tongues of the other two Aktru glaciers. The three Aktru glaciers are highly 10 representative for the entire ensemble of glaciers in the region, because they cover the majority of glacier sizes, elevation ranges and aspect directions. Still the error for the debris thickness on the individual glaciers can only be estimated to be less than $20 \%$ for debris thicknesses smaller than $20 \mathrm{~cm}$. For thicker debris the error is higher, but not significant, as the ice melt sensitivity in respect to debris thickness is very low.

15 During the beginning of the ablation period first the snow cover needs to be melted, before the ice melt can start. For the snow cover during the accumulation season, there are only mean winter balance values available. For our model study we assume that the snow cover is evenly distributed over the ablation area and use a degree day factor similar to the values in Singh et al. (2000) for simulating snow melt. Differences 20 in the spatial distribution of the snow cover could introduce some uncertainties in our analysis. But the main aim of the study is the evaluation of ice melt in dependence of debris cover. The correct representation of snow melt run-off has only a minor influence on this mechanism, mainly concerning the onset of ice melt after removal of the snow pack.

25 Based on the observed ablation conditions at Maliy Aktru glacier described above, the relation between the debris thickness dependent ablation and the air temperature is determined, resulting in the function of degree day factors. These degree day factors then are used for the entire area, assuming no significant change in geology and

$5,401-430,2011$

Glacial debris cover and melt water production for glaciers

C. Mayer et al.

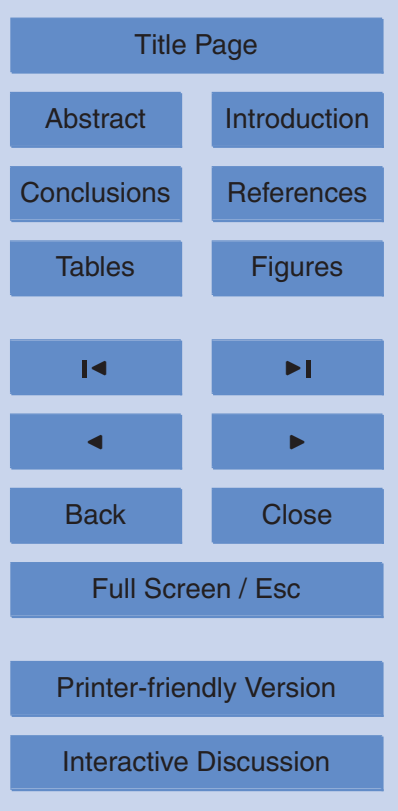

Interactive Discussion 
morphology within this rather small region of interest (approx. 15 by $10 \mathrm{~km}^{2}$ ).

Three different areas are simulated with the melt model:

1. Maliy Aktru glacier is used for evaluating the absolute melt rates, because for this glacier mass balance values are available and the model parameters have been directly derived from field work.

2. The three glaciers in the Aktru basin are combined in a second model region, in order to evaluate the influence of the ice melt on the discharge from this basin.

3. The entire area is used for determining the significance of the debris cover on the ice melt in a larger region.

10 For all the glaciers the area-elevation distribution derived from the remote sensing analysis is used as basis for the simulations.

\section{Simulation results and discussion}

\subsection{Maliy Aktru glacier}

Maliy Aktru glacier has only a rather limited debris cover and therefore it was not expected that there are large differences between ice melt for the clean glacier case and the results including the actual debris cover. The measured mass balance of Maliy Aktru was negative for all the years of our test period 2000 until 2003 (Table 3).

The net balance versus altitude for Maliy Aktru is almost linear in the ablation zone and we use the ice loss at the glacier terminus and the ELA (zero mass balance) as the two control points for our model calibration. The winter balance did not show strong variations and was close to its long term mean value of $660 \mathrm{~mm}$ for all the four years. The model simulates the conditions of the years 2000-2002 rather well (Table 4) for the given degree day relations. For 2003, however, the degree day factor for snow needs to be about $40 \%$ higher than the initial value in order to match the boundary conditions

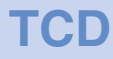

5, 401-430, 2011

Glacial debris cover and melt water production for glaciers

C. Mayer et al.

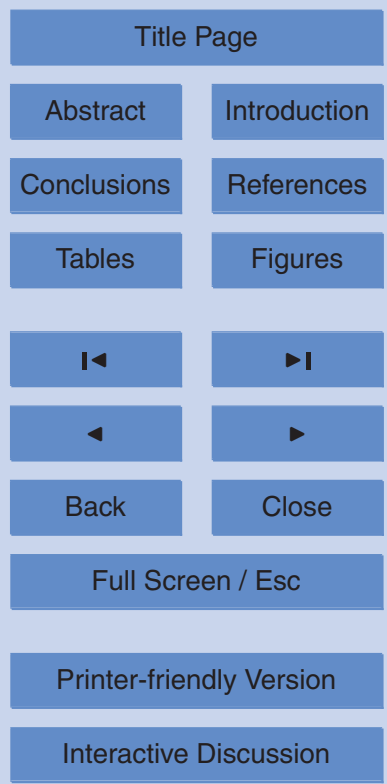


The reasons for the changed conditions in 2003 are not known, but a different distribution of snow could easily explain such variations. In order to make the simulations comparable, we therefore only use the years 2000 until 2002 for the comparison with the other model experiments. Already the limited debris cover of Maliy Aktru strongly 5 influences the shape of the net balance curve (Fig. 6) and total melt is considerably less than for the clean ice situation. Depending on the individual year, the difference in total ice melt on the glacier compared to the clean ice case varies from $8 \%$ to $10 \%$, whereas during more negative balance years the difference is smaller. The mean melt reaches values close to the clean ice case only in areas where the area of debris cover

10 is very small. This is in good agreement with more theoretical calculations of Reid and Brock (2010) for the situation at Miage glacier, Italy.

\subsection{The glaciers in the Aktru basin}

For the entire Aktru basin the ablation conditions are investigated in detail. Compared to the North-exposed glacier tongue of Maliy Aktru, the ablation zones of the other 5 glaciers receive more radiation (Fig. 7). Quantitative consequences from the different surface energy balance are difficult to determine. Therefore we restrict our analysis to estimate the relative influence of the radiation budget on the basis of the potential solar radiation input, similar to the approach of Hock (1999) for her distributed mass balance model: During the main melt season in July, the ablation zone of Leviy Aktru receives 20 about $90 \%$ more energy as the same zone at Maliy Aktru on clear days, based on our radiation analysis (Fig. 7). For Pravjy Aktru this relation is about $60 \%$. Over clean ice the major part of this additional energy is reflected due to the higher albedo of clean ice (0.4-0.5, e.g. Knap and Reijmer, 1998) compared to the debris cover, while on the debris cover the incoming radiation will be absorbed to a higher degree, producing 25 higher debris surface temperatures. The debris cover of all three glaciers is about $11 \%$ of the total area of the glaciers, representing about $24 \%$ of the ablation area. Thus the effect of higher radiation absorption due to the existence of a debris cover is limited to less than a quarter of the ablation area. Based on typical albedo values for the

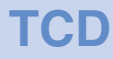

$5,401-430,2011$

Glacial debris cover and melt water production for glaciers

C. Mayer et al.

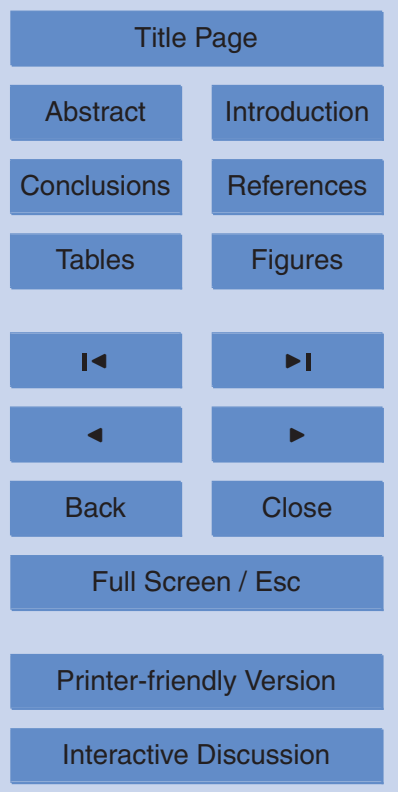

Interactive Discussion 
supra-glacial debris we estimate that about half of the additional energy due to a more favorable exposition is used for melting clean ice, because the temperature of melting ice is limited to $0{ }^{\circ} \mathrm{C}$ and higher radiation amounts cannot be fully exploited. In the case of sub-debris melt, the debris surface temperatures can reach rather high values; thus 5 we estimate the effect of the enhanced radiation on ice melt to be about $90 \%$ in this case. Combining these two effects and taking into account the spatial relation between clean ice and debris cover, the mean melt rates for all three Aktru glaciers should be higher by a factor of 1.2 compared to Maliy Aktru alone. The mean equilibrium line altitude for all glaciers is about $100 \mathrm{~m}$ lower than the result for the Maliy Aktru simulation 10 and the long term ELA of Maliy Aktru (Haeberli et al., 2007) which is probably due to more favorable accumulation conditions on Leviy and Praviy Aktru glaciers.

Considering the difference between melt water production for the clean ice case and the debris cover, the values vary from $12 \%$ to $15 \%$, which is due to a higher debris cover of the tongue of Praviy Aktru. An example of the simulation results for all Aktru glaciers is given in Fig. 8. The differences between clean-ice melt and melt underneath the local debris cover reach more than $100 \%$ in some elevation bands, while the mean difference is about $35-45 \%$. These findings are comparable to results from other studies (e.g. Nicholson and Benn, 2006), where the relative impact of the debris cover varies between 11 and more than $30 \%$. In respect to total melt water production no comparable studies exist so far. By using a conceptual run-off model and including a supra-glacial debris cover, Rana et al. (1997) simulate the discharge in the glacierized Lirung basin in Nepal. Their conclusion of a discharge reduction of more than $50 \%$ during summer time due to the existence of supra-glacial debris is in the same order than our results. However, the relative debris cover and thickness is more pronounced in the Lirung basin.

Unfortunately there are only some scattered run-off data available for the Aktru basin, for some years in the 1960s and 1970s. In these years, the summer run-off from June until September was rather constant with a mean value of 9.8 million cubic meters and a standard deviation of 1.3 million cubic meters. Apart from rain, run-off in the summer

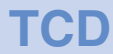

$5,401-430,2011$

Glacial debris cover and melt water production for glaciers

C. Mayer et al.

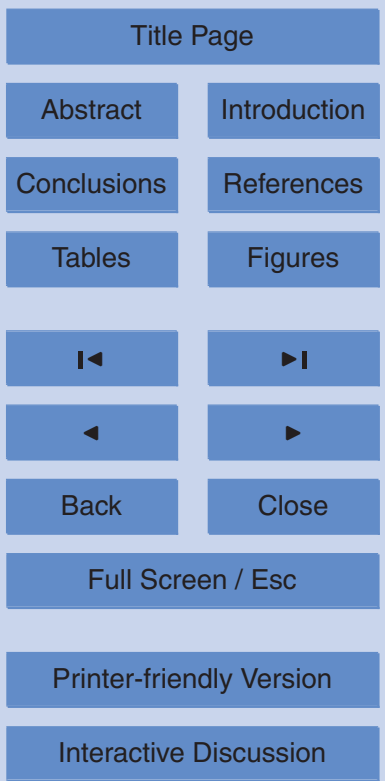


during this period is mainly governed by ice melt and only to a minor extent by snow melt. Therefore these measurements can be compared to the simulated ice melt, which will also be produced during the same months of the year. The mean amount of ice melt from the three glaciers is 6.6 million cubic metres of water, which corresponds to a 5 fraction of $67 \%$ of the total run-off during the summer months, assuming that summer run-off in 2000-2002 was similar than during the 1960s and 1970s. In reality, ice ablation and thus summer run-off would be slightly reduced, using the same boundary conditions, due to an increased debris cover and a smaller glacier extent compared to three decades earlier. For the clean ice case and still under identical boundary 10 conditions, the total run-off would be higher, resulting in 10.8 million cubic metres and the ratio of melt water in this case would be $70 \%$. This is a rather high value even for a drainage basin which is $44 \%$ glacier covered.

A comparison of the mean summer temperatures (JJAS) between the two time periods resulted in $13 \%$ higher temperatures for the beginning of the millennium $\left(11.1^{\circ} \mathrm{C}\right.$ to $\left.12.6^{\circ} \mathrm{C}\right)$. Thus discharge of melt water was probably higher during this time and thus the fraction of melt water from the debris covered glaciers somewhat lower than the simulated $67 \%$.

\subsection{Run-off in the investigated region in the North Chusky Range}

For the simulation of all 12 glaciers in the investigated area, the variation of the ratio

between debris covered ice melt and the clean glacier case is $77 \%-80 \%$ and thus run-off is reduced by about $20 \%$ due to the effect of the supra glacial debris cover which again corresponds well with other investigations (e.g. Nicholson and Benn, 2006; Reid and Brock, 2010; Lambrecht et al., 2011). The contribution of the glaciers to the hydrology in this area is in the order of 28 million cubic meters for the moderately negative balance years 2000-2002. This is about four times the glacier contribution in the Aktru basin. This compares well with the relative glacier area of the Aktru glaciers in respect to the glacier entire group.

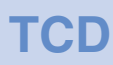

$5,401-430,2011$

Glacial debris cover and melt water production for glaciers

C. Mayer et al.

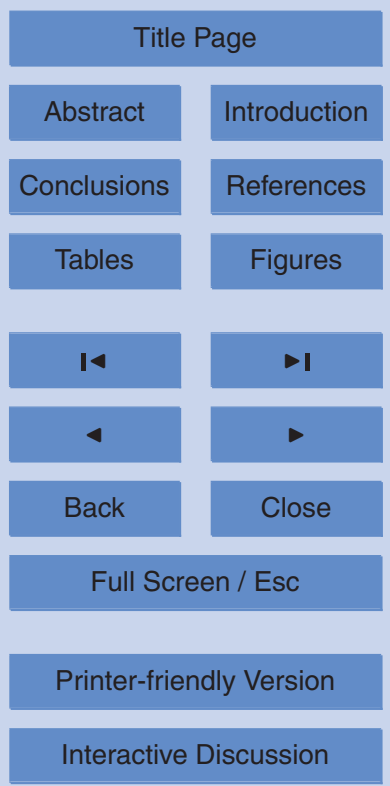




\section{Conclusions}

The model developed in this study is able to realistically simulate the ice melt production from debris covered glaciers. Basis for this is the existence of a daily temperature record and at least some years of mass balance studies. Also field data about the 5 thermal conditions of the supra-glacial debris and its thickness variability are required, as well as an analysis of the spatial debris distribution and an area-elevation distribution of glacier ice and debris cover. For the North Chusky Range calibration of the model and comparison with basin run-off could only be estimated, because of gaps in the data basis. Nevertheless it could be shown that the Maliy Aktru glacier mass balance could be reproduced for the test period. Due to an only moderate debris cover on the sample glaciers the amount of glacier melt water is reduced by about $20 \%$ in respect to clean ice conditions. The influence of glacier melt to the summer run-off (JJAS), investigated in the Aktru basin, is at least higher than $60 \%$ und thus a major contribution.

Even this moderate reduction in total ice melt of $20 \%$ is based on differences in net balance at the glacier tongues in the order of $1.5 \mathrm{~m}$ per year.

The analysis of the long term summer mean temperatures reveals a rather moderate warming trend during the major part of the 20th century. Only during the last decade the summer temperatures increased strongly, starting a period of almost continuous negative mass balances (as referred from the Maliy Aktru time series). This also coincides with the strong increase in debris cover after the year 2000 (Fig. 3). A further rise in temperatures resulting in higher debris yield from thawing periglacial permafrost and intensified melt rates will accelerate this debris cover increase even more. A stronger protection of the glacier tongues, a dampening of the temperature governed increased ice melt and thus a smaller than expected melt water contribution to summer run-off will be the consequences.

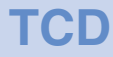

5, 401-430, 2011

Glacial debris cover and melt water production for glaciers

C. Mayer et al.

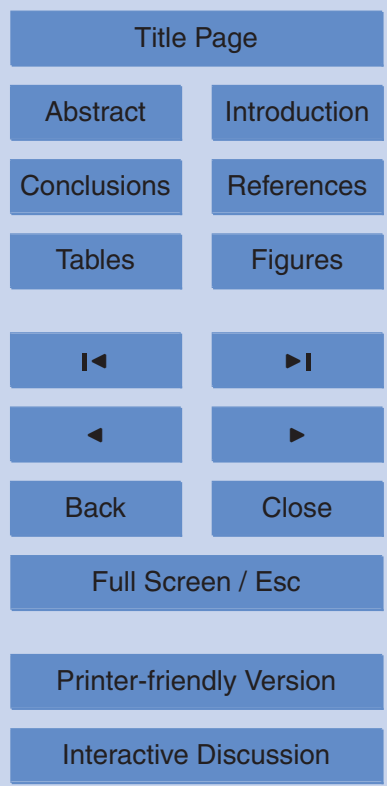


Acknowledgements. We gratefully acknowledge the financial support by the EU-INTAS project "Evaluating the Recent and Future Climate Change and Glacier Dynamics in the Mountains of Southern Siberia" and the "EGREW" project of the Austrian Academy of Sciences. Also we want to thank all our colleagues from the Tomsk University for very valuable support during the 5 field work.

\section{References}

Adhikary, S., Nakawo, M., Seko, K., Shakya, B.: Dust influence on the melting process of glacier ice: experimental results from Lirung Glacier, Nepal Himalayas, IAHS Publ. 264 (Symposium at Seattle 2000 - Debris-Covered Glaciers), 43-52, 2000.

Aizen, V. B., Kuzmichenok, V. A., Surazakov, A. B., and Aizen E. M.: Glacier changes in the Tien Shan as determined from topographic and remotely sensed data, Global and Planetary Change, 56(3-4), 328-340, doi:10.1016/j.gloplacha.2006.07.016, 2007.

Bolch, T.: Climate change and glacier retreat in northern Tien Shan (Kazakhstan/Kyrgyzstan) using remote sensing data, Global and Planetary Change, 56(1-2), 115 12, doi:10.1016/j.gloplacha.2006.07.009, 2007.

Braithwaite, R. J.: Positive degree-day factors for ablation on the Greenland ice sheet studied by energy-balance modelling, J. Glaciol., 41(137), 153-160, 1995.

Haeberli, W., Hoelzle, M., Zemp, M.: Glacier Mass Balance Bulletin, No. 9, ICSU (FAGS) IUGG (IACS) - UNEP - UNESCO - WMO, 100 pp., 2007.

Hagg, W., Mayer, C., Lambrecht, A., and Helm, A.: Sub-debris melt rates on southern Inylchek Glacier, central Tian Shan, Geogr. Ann. A, 90(1), 55-63, 2008.

Hock, R.: A distributed temperature-index ice- and snowmelt model including potential direct solar radiation, J. Glaciol., 45(149), 101-111, 1999.

Jarvis, A., Reuter, H. I., Nelson, A., and Guevara, E.: Hole-filled seamless SRTM data V4, International Centre for tropical Agriculture (CIAT), available at: http://srtm.csi.cgiar.org/, 2008.

Kayastha, R. B.,Takeuchi, Y., Nakawo, M., and Ageta, Y.: Practical prediction of ice melting beneath various thickness of debris cover on Khumbu Glacier, Nepal using a positive degree day factor, IAHS Publ. 264 (Symposium at Seattle 2000 - Debris-Covered Glaciers), 71-81, 2000.

Konovalov, V.: Computations of melting under moraines as a part of regional modelling of

\section{Glacial debris cover and melt water production for glaciers \\ C. Mayer et al.}

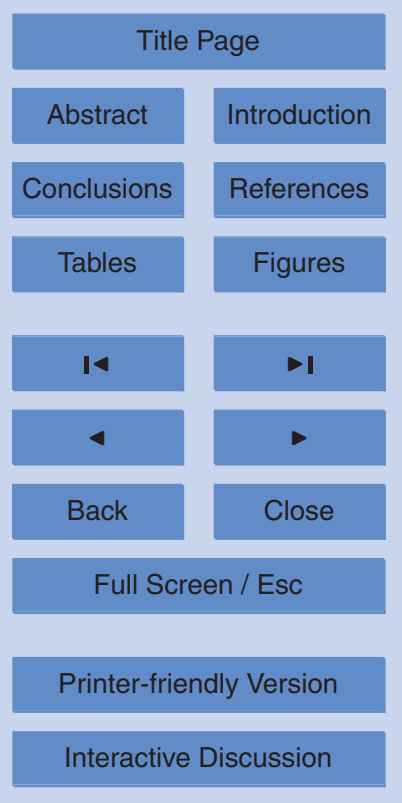


glacier runoff, IAHS Publ. 264 (Symposium at Seattle 2000 - Debris Covered Glaciers), 109-118, 2000.

Lambrecht, A. and Kuhn, M.: Glacier changes in the Austrian Alps during the last three decades, derived from the new Austrian glacier inventory, Ann. Glaciol., 46, 177-184, 2007.

5 Lambrecht, A., Mayer, C., Hagg, W., Popovnin, V., Rezepkin, A., Lomidze, N., and Svanadze, D.: A comparison of glacier melt on debris-covered glaciers in the northern and southern Caucasus, The Cryosphere Discuss., 5, 431-459, doi:10.5194/tcd-5-431-2011, 2011.

Mattson, L. E., Gardener J. S., and Young, G. J.: Ablation on debris covered glaciers: an example from the Rakhiot Glacier, Panjab, Himalaya, IAHS Publ. 218 (Workshop at Seattle 102000 - Debris-Covered Glaciers), 289-296, 1993.

Mayer, C., Lambrecht, A., Mihalcea, C., Belò, M.,Diolaiuti, G., Smiraglia, G., and Bashir, F.: Analysis of glacial meltwater in Bagrot Valley, Karakoram: Based on short-term ablation and debris cover observations on Hinarche Glacier, Mt. Res. Dev., 30(2), 169-177, 2010.

Mihalcea, C., Mayer, C., Diolaiuti, G., Lambrecht, A., Smiraglia, C., and Tatari, G.: Ice ablation 15 and meteorological conditions on the debris-covered area of Baltoro glacier, Karakoram, Pakistan, Ann. Glaciol., 43, 292-300, 2006.

Moribayashi, S. and Higuchi, K.: Characteristics of glaciers in the Khumbu region and their recent variations, Seppyo, 39, 3-6, 1977.

Nakawo, M. and Takahashi, S.: A simplified model for estimating glacier ablation und a debris layer, IAHS Publ. 138, 137-145, 1982.

Narozhny, Y., Nikitin, S., and Lukianov, A.: Changes in the extent of glaciers in the Russian Altay in the second half of the $20^{\text {th }}$ century, in: Selected papers from the Workshop "Assessment of Snow, Glacier and Water Resources in Asia", Almaty, Kazakhstan, 28-30 November 2006, 128-131, 2009.

25 Narozhny, Y. K., Nikitin, S. A., and Borodavko P. S.: Ledniki gornogo uzla Belukhi (Altai): massoobmen, dinamika i raspredelenie zapasov l'da (Glaciers of the Belukha (Altai) mountain knot: mass turnover, dynamics and ice storage distribution): Data of Glaciological Studies, 101, 51-60, 2006 (in Russian).

Nicholson, L., Benn, D.I.: Calculating ice melt beneatha debris layer using meteorological data, J. Glaciol., 52 (178), 463-470, 2006.

Østrem, G.: Ice melting under a thin layer of moraine, and the existence of ice cores in moraine ridges, Geogr. Ann., 41(4), 228-230, 1959.

Paul, F., Kääb, A., Maisch, M., Kellenberger,T., and Haeberli, W.: Rapid disinte-

Glacial debris cover and melt water production for glaciers

C. Mayer et al.

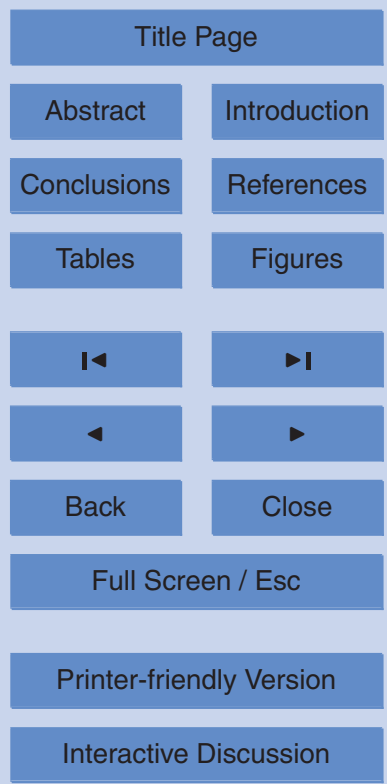


gration of Alpine glaciers observed with satellite data, Geophys. Res. Lett., 31(21), doi:10.1029/2004GL020816, 2004.

Rana, B., Nakawo, M., Fukushima, Y., and Ageta, Y.: Application of a conceptual precipitationrunoff model (HYCYMODEL) in a debris-covered glacierized baisn in the Langtang Valley,

$5 \quad$ Nepal Himalaya, Ann. Glaciol., 35, 226-231, 1997.

Reid, T. D. and Brock, B. W.: An energy-balance model for debris-covered glaciers including heat conduction through the debris layer, J. Glaciol., 56(199), 903-915, 2010.

Singh, P., Kumar, N., Ramasastri, K. S., and Singh Y.: Influence of a fine debris layer on the melting of snow and ice on a Himalayan glacier, IAHS-AISH Publ. 264 (Symposium at Seattle 2000 - Debris Covered Glaciers), 63-70, 2000.

Shetinnikov, A. S.: Morfologiya i rezhim lednikov Pamiro-Alaya (The morphology and regime of Pamir-Alai glaciers), Central Asia Hydro- Meteorological Institute, Tashkent, 219 pp., 1998.

Smiraglia, C., Diolaiuti, G., Casati, D., Krikbride, M.: Recent areal and altimetric variations of Miage Glacier (Monte Bianco massif, Italian Alps), IAHS Publ. 264, (Workshop at Seattle 2000 - Debris-Covered Glaciers), 227-234, 2000.

Surazakov, A. B., Aizen, V. B., Aizen, E. M., and Nikitin, S. A.: Glacier changes in the Siberian Altai Mountains, Ob river basin, (1952-2006) estimated with high resolution imagery, Environ. Res. Lett., 2, doi:10.1088/1748-9326/2/4/045017, 2007.

Yang, J. P. Ding, Y. J., Chen, R. S., Li, S. Y., and Lu, A. X.: Causes of glacier change in the source regions of the Yangtze and Yellow rivers on the Tibetan Plateau. J. Glaciol., 49(167), 539-46, 2003.

\section{Glacial debris cover and melt water production for glaciers \\ C. Mayer et al.}

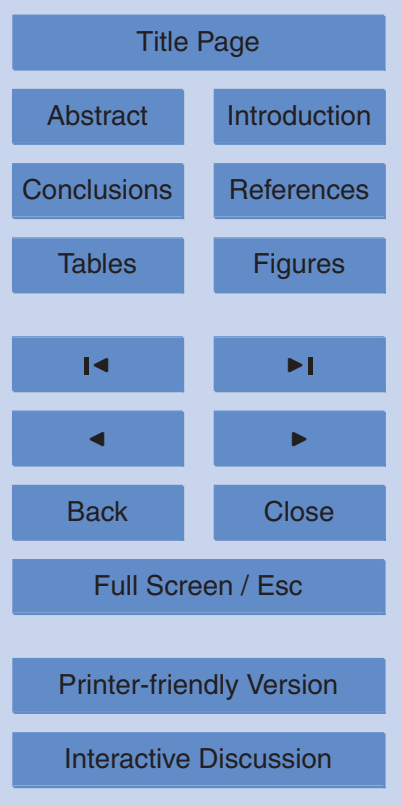




\section{TCD}

\section{$5,401-430,2011$}

Glacial debris cover and melt water

production for glaciers

Table 1. Glacier and debris cover evolution of the twelve glaciers between 1966 and 2008.

\begin{tabular}{lccccccc}
\hline Glacier name & \multicolumn{2}{c}{ Glacier area $\left(\mathrm{km}^{2}\right)$} & \multicolumn{2}{c}{ Debris area $\left(\mathrm{km}^{2}\right)$} & \multicolumn{2}{c}{ Glacier area change (\%) } & \multicolumn{2}{c}{ Debris cover ratio (\%) } \\
& 2008 & 1966 & 2008 & 1966 & $1996-2008$ & 2008 & 1966 \\
\hline Bol'shoi Ouk & 4.19 & 4.71 & 0.29 & 0.16 & -10.97 & 6.87 & 3.45 \\
Praviy Karagemsky & 2.59 & 3.00 & 0.24 & 0.30 & -13.82 & 9.22 & 10.02 \\
G087642E50061N & 0.91 & 1.01 & 0.03 & 0.04 & -9.90 & 3.72 & 3.69 \\
Leviy Karagemsky & 6.99 & 7.56 & 0.29 & 0.08 & -7.51 & 4.11 & 1.12 \\
Jelo & 7.41 & 7.77 & 0.76 & 0.20 & -4.53 & 10.21 & 2.59 \\
G087670E50072N & 4.98 & 5.23 & 1.08 & 0.89 & -4.76 & 21.7 & 16.97 \\
Maliy Aktru & 2.90 & 3.09 & 0.16 & 0.14 & -6.00 & 5.47 & 4.59 \\
Praviy Aktru & 4.69 & 4.98 & 0.83 & 0.83 & -5.83 & 17.75 & 16.6 \\
Leviy Aktru & 5.96 & 6.21 & 0.52 & 0.16 & -4.16 & 8.81 & 2.64 \\
Yan-Karasu & 2.30 & 2.69 & 0.59 & 0.69 & -14.53 & 25.8 & 25.7 \\
Korumdu & 3.84 & 4.00 & 0.33 & 0.25 & -3.96 & 8.62 & 6.17 \\
Mashey & 9.48 & 9.91 & 1.78 & 1.84 & -4.37 & 18.73 & 18.56 \\
total/mean & 56.24 & 60.16 & 6.90 & 5.59 & -6.51 & 11.75 & 9.34 \\
\hline
\end{tabular}

C. Mayer et al.

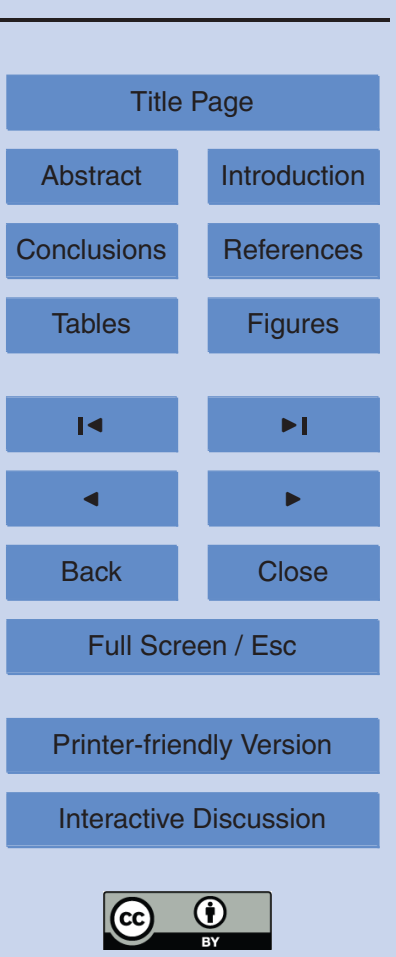


Table 2. Summary of the satellite images/aerial photographs used for the debris mapping.

\begin{tabular}{llc}
\hline sensor & Date & resolution $(\mathrm{m})$ \\
\hline aerial photographs & 1952 & 3 \\
Corona (KH-7) & $19 / 08 / 1966$ & 4 \\
Spot & $06 / 08 / 2008$ & 10 \\
Landsat 7 & $22 / 07 / 2000,28 / 07 / 2008$ & 30 \\
\hline
\end{tabular}

Glacial debris cover and melt water production for glaciers

C. Mayer et al.

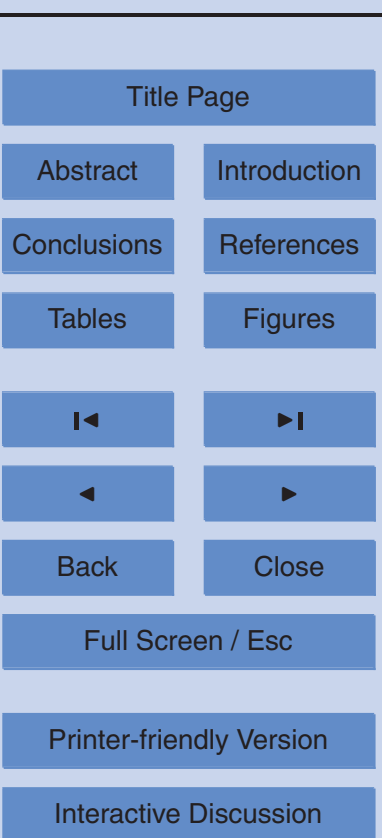


$5,401-430,2011$

Table 3. Mass balance of Maliy Aktru glacier for the years 2000 until 2003, including the net balance $b_{n}$, the winter balance $b_{w}$, the equilibrium line altitude ELA and the ice loss at the glacier snout (Haeberli et al., 2007).

\begin{tabular}{ccccc}
\hline Year & $\mathrm{b}_{n}(\mathrm{~mm})$ & $\mathrm{b}_{w}(\mathrm{~mm})$ & ELA $(\mathrm{m})$ & ice loss at snout $(\mathrm{mm})$ \\
\hline 2000 & -210 & 720 & 3250 & -4500 \\
2001 & -190 & 630 & 3240 & -4600 \\
2002 & -410 & 520 & 3260 & -4750 \\
2003 & -370 & 500 & 3260 & -4600 \\
\hline
\end{tabular}

Glacial debris cover and melt water production for glaciers

C. Mayer et al.

Title Page

\section{Abstract} Introduction

Conclusions References

Tables Figures

14

4

Back

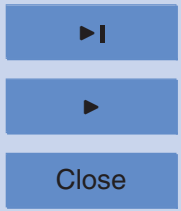

Full Screen / Esc

Printer-friendly Version

Interactive Discussion 
$5,401-430,2011$

Table 4. Model results for Maliy Aktru glacier, providing information about the elevation of zero mass balance (ELA) and the ice loss at the glacier snout for the years 2000 until 2003. The corrected values for 2003 were calculated with a changed degree day factor for snow as described in the text.

\begin{tabular}{lcc}
\hline Year & ELA $(\mathrm{m})$ & Ice loss at snout $(\mathrm{mm})$ \\
\hline 2001 & 3230 & -4460 \\
2001 & 3260 & -4370 \\
2002 & 3280 & -4770 \\
2003 & 3150 & -4000 \\
2003 (corr.) & 3270 & -4590 \\
\hline
\end{tabular}

Glacial debris cover and melt water production for glaciers

C. Mayer et al.

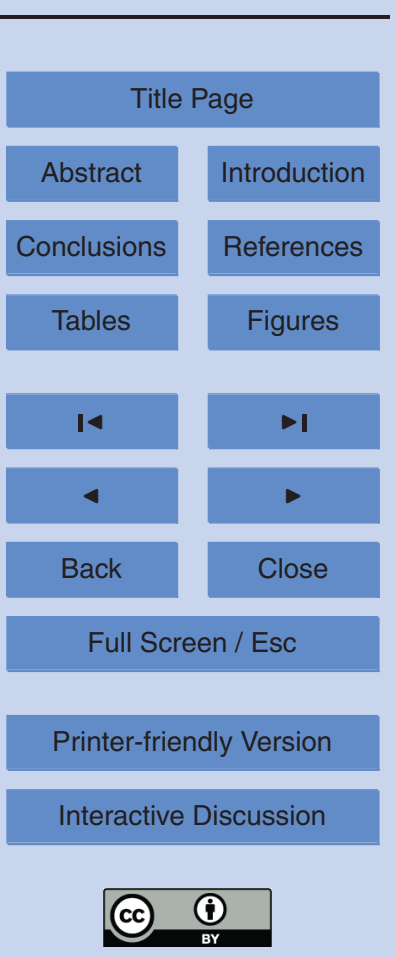




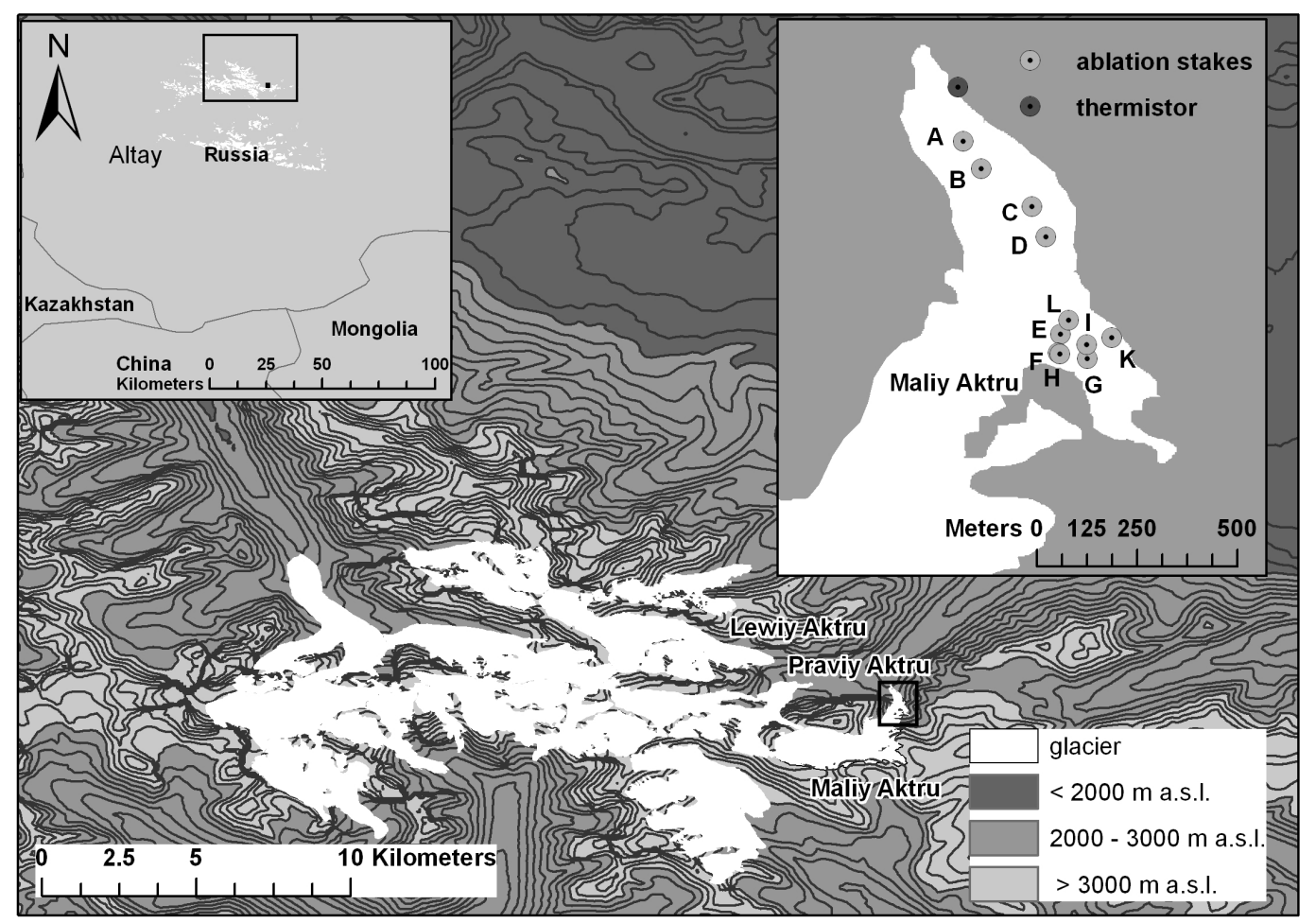

Fig. 1. Overview of the area of investigation and its location in the Russian Altay region. The glaciers are shown in white, whereas the gray shades represent the $1000 \mathrm{~m}$ altitude bands. The inset shows the stake distribution on the debris covered part of the Maliy Aktru glacier.

\section{TCD}

$5,401-430,2011$

Glacial debris cover and melt water production for glaciers

C. Mayer et al.

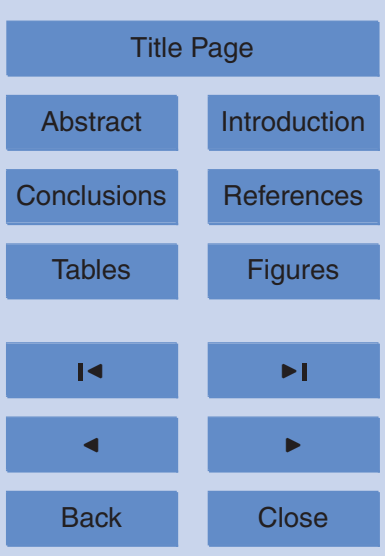

Full Screen / Esc

Printer-friendly Version

Interactive Discussion 


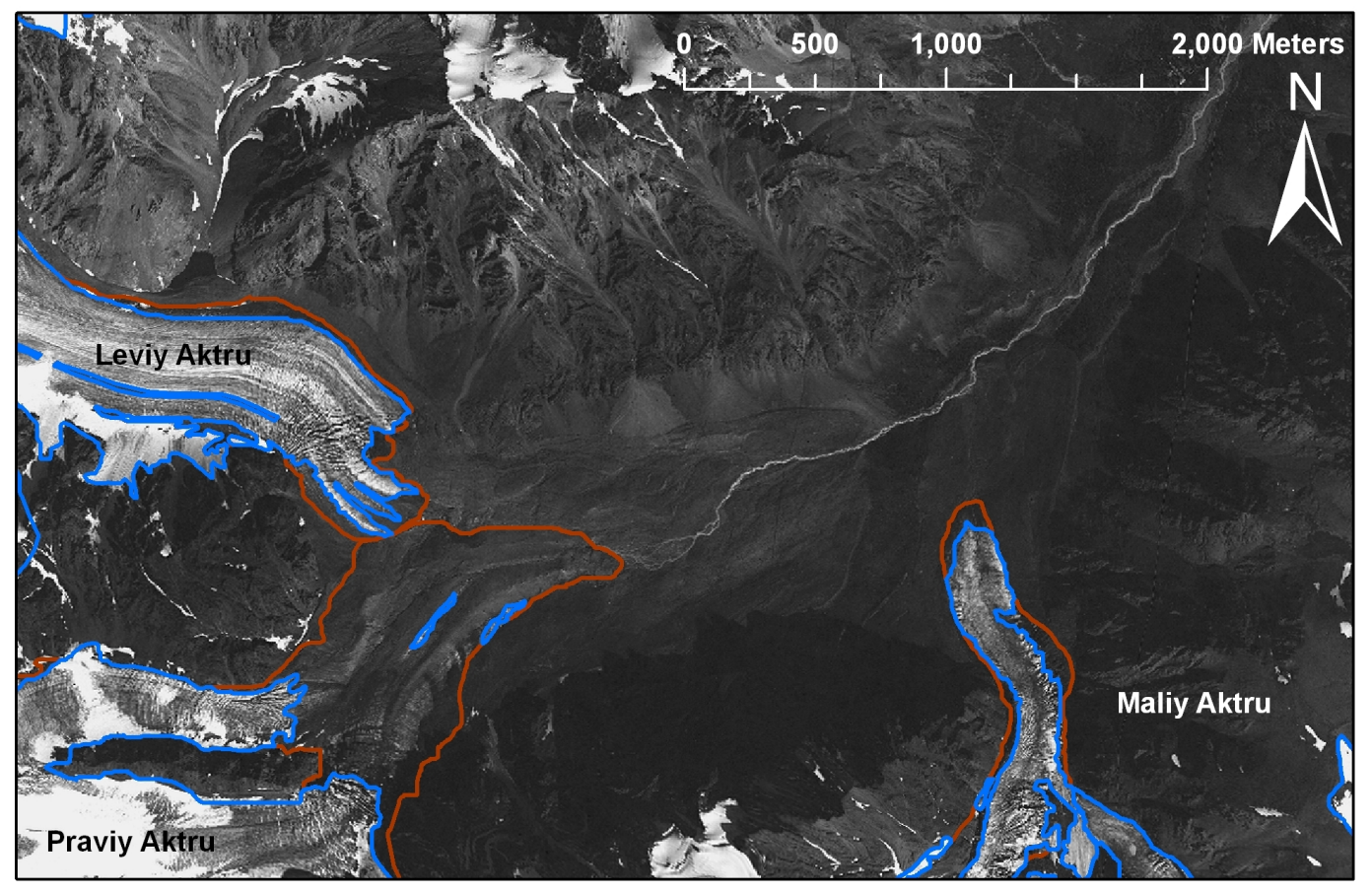

Fig. 2. Tongues of the three Aktru glaciers with the delineation of clean ice extent (blue line) and the debris covered parts (orange line) on the basis of the 1966 Corona image.

\section{TCD}

$5,401-430,2011$

Glacial debris cover and melt water production for glaciers

C. Mayer et al.

Title Page

\section{Abstract}

Conclusions

\section{Tables}

14

4

Back
Introduction

References
Figures

$>$ I

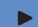

Close

\section{Full Screen / Esc}

Printer-friendly Version

Interactive Discussion 


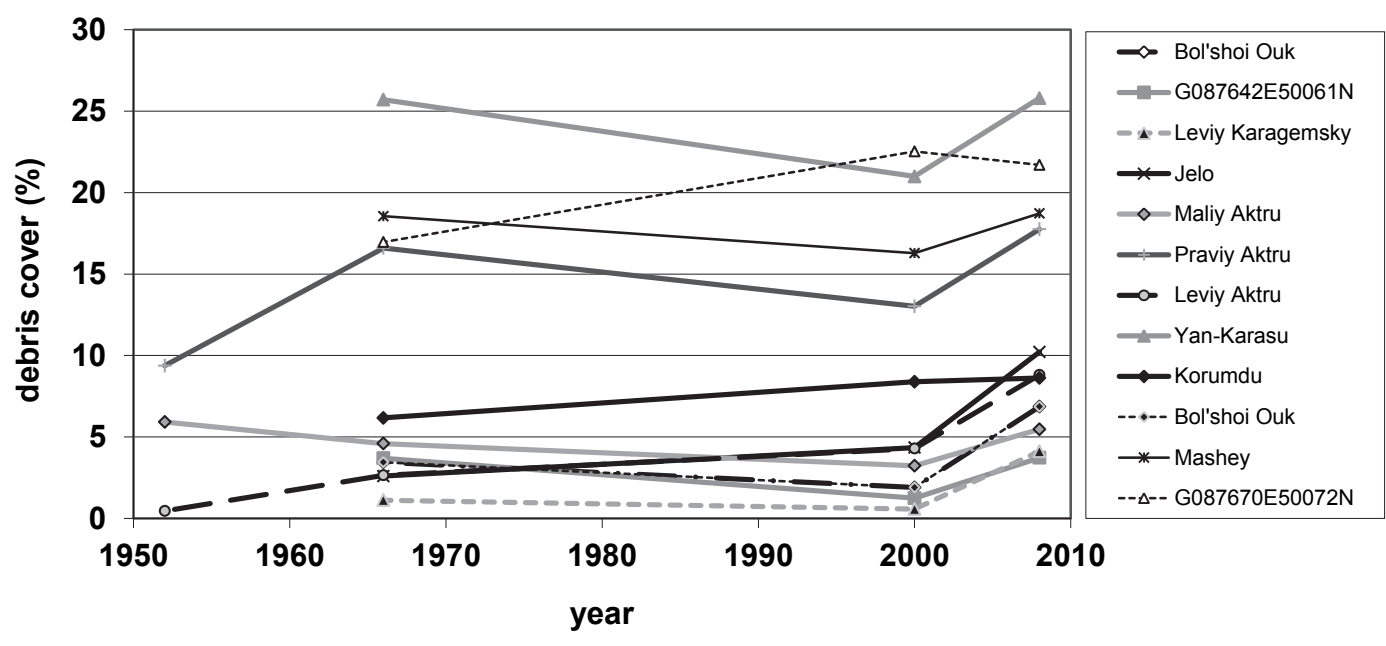

Fig. 3. Debris cover evolution of the twelve investigated glaciers of the North Chuya Range between 1952 and 2008, based on different remote sensing images as described in Table 2.

\section{TCD}

5, 401-430, 2011

\section{Glacial debris cover and melt water production for glaciers \\ C. Mayer et al.}

\section{Title Page}

\section{Abstract} Introduction

Conclusions References

Tables Figures

14

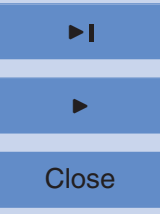

Back

Full Screen / Esc

Printer-friendly Version

Interactive Discussion 


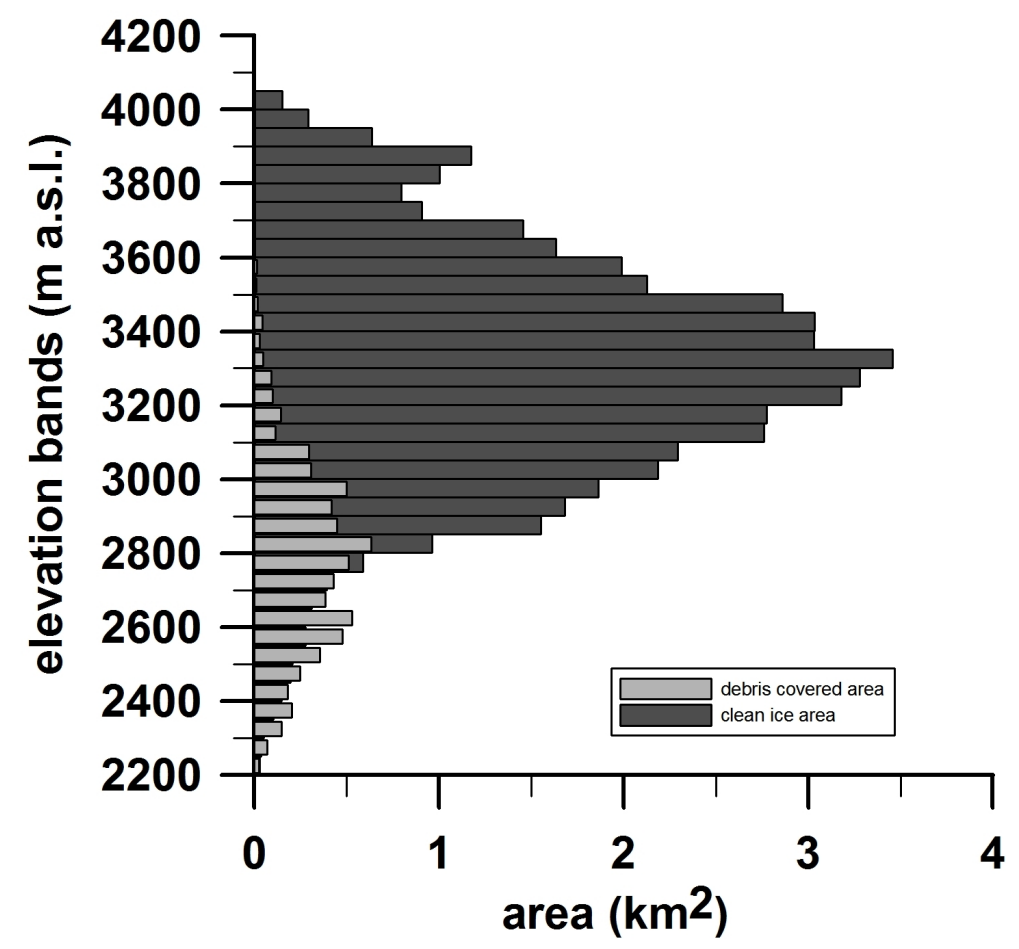

Fig. 4. Area elevation distribution for the twelve glaciers included in this study. The dark bars show the distribution of the clean glacier ice, whereas the bright bars indicate the debris covered ice areas.

\section{$5,401-430,2011$}

\section{Glacial debris cover and melt water production for glaciers \\ C. Mayer et al.}

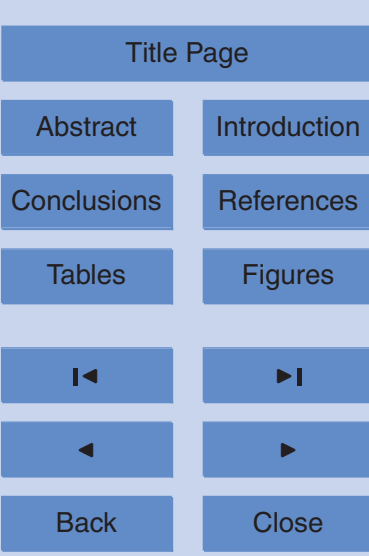

Full Screen / Esc

Printer-friendly Version

Interactive Discussion 


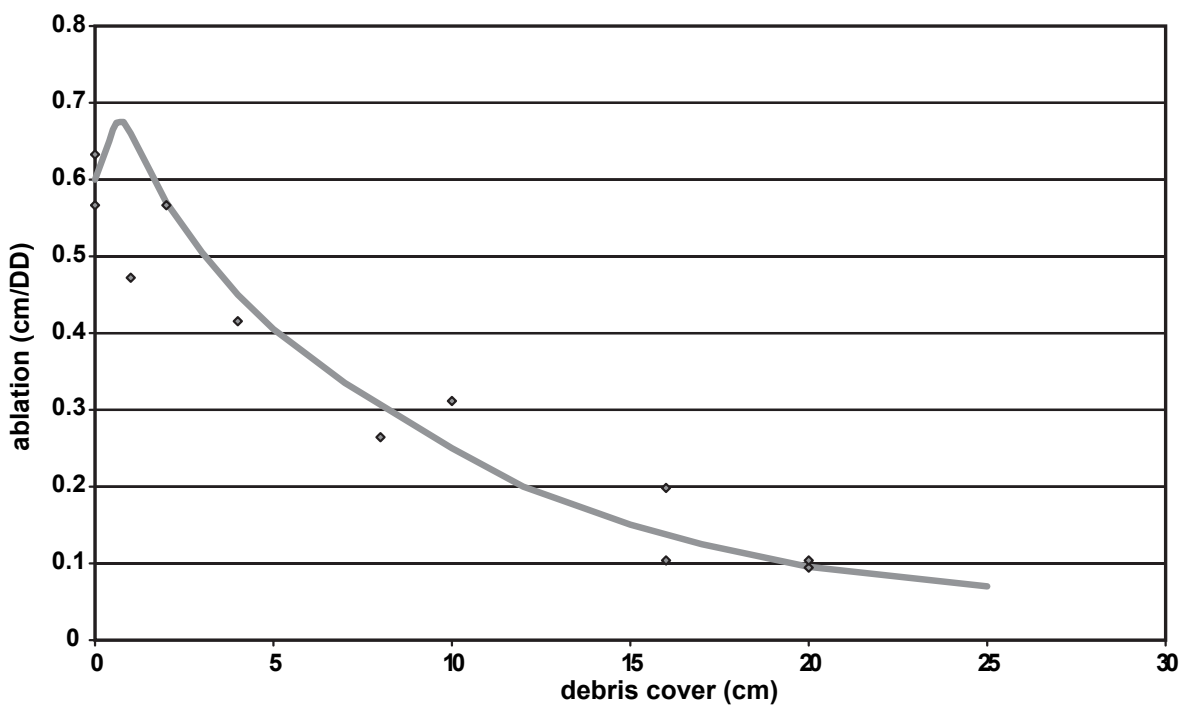

Fig. 5. Ice ablation in centimetres per positive degree day in dependence of the debris cover thickness. The value at $1 \mathrm{~cm}$ debris thickness is influenced by temporal changes in the debris cover and therefore was not used for determining the relation between ablation and debris thickness (solid line).
TCD

5, 401-430, 2011

\section{Glacial debris cover and melt water production for glaciers \\ C. Mayer et al.}

\section{Title Page}

\section{Abstract}

Introduction

Conclusions

References

Tables

Figures

14

$>1$

$\triangleleft$

Back

Close

Full Screen / Esc

Printer-friendly Version

Interactive Discussion 


\section{TCD}

$5,401-430,2011$

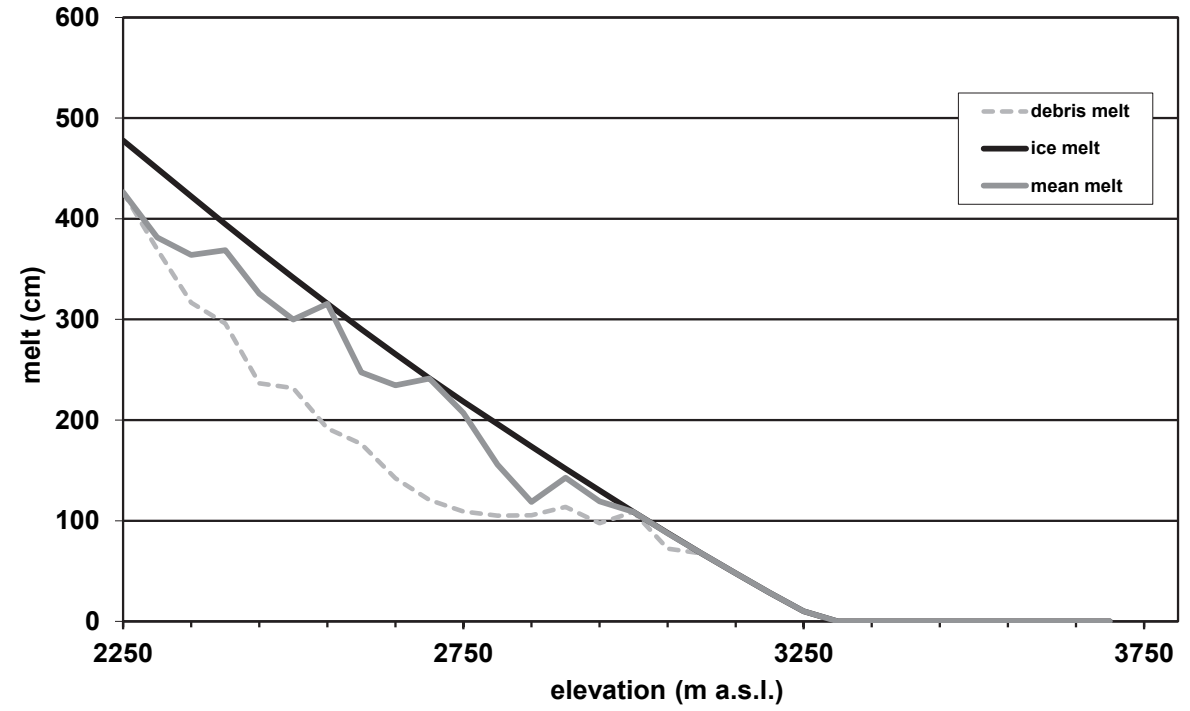

\section{Glacial debris cover and melt water production for glaciers \\ C. Mayer et al.}

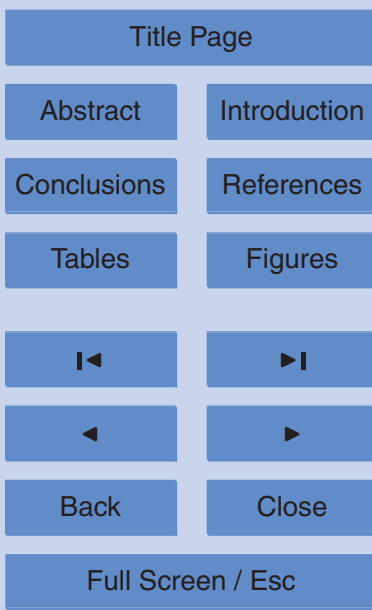

Fig. 6. Model results for the simulation of ice melt on Maliy Aktru glacier for the year 2000. Debris melt is the total ice melt under a $100 \%$ debris cover, based on the debris thickness distribution described in the text. Ice melt describes the distribution of ablation with altitude for the absence of any debris cover. Mean melt is the resulting ice melt with the correct distribution of debris extent and thickness.

Printer-friendly Version

Interactive Discussion 


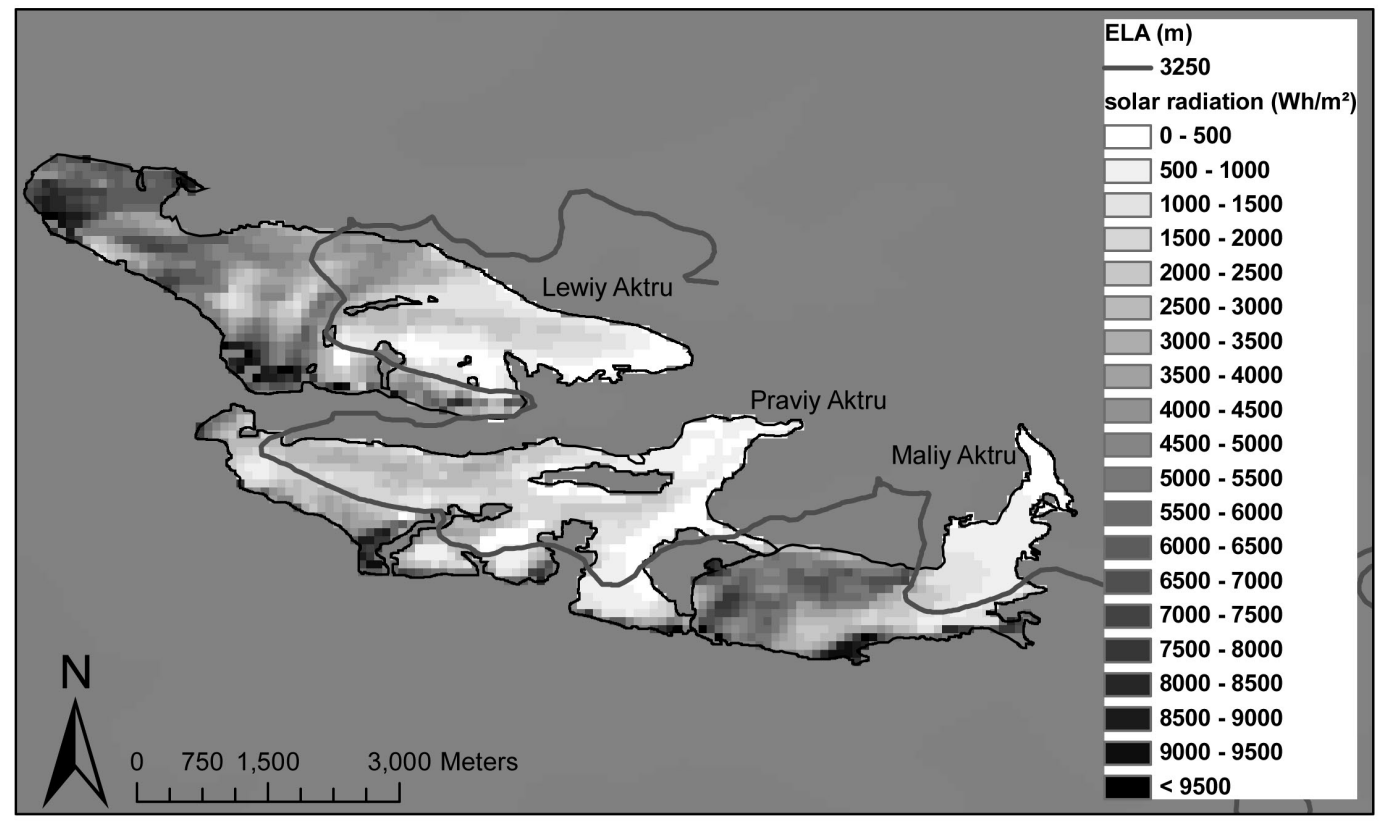

Fig. 7. Calculated clear sky daily incoming solar radiation on the Aktru glaciers for the conditions of 15 July, during the main ablation season. Shading is calculated on the basis of the SRTM digital elevation model.

\section{TCD}

$5,401-430,2011$

\section{Glacial debris cover and melt water production for glaciers \\ C. Mayer et al.}

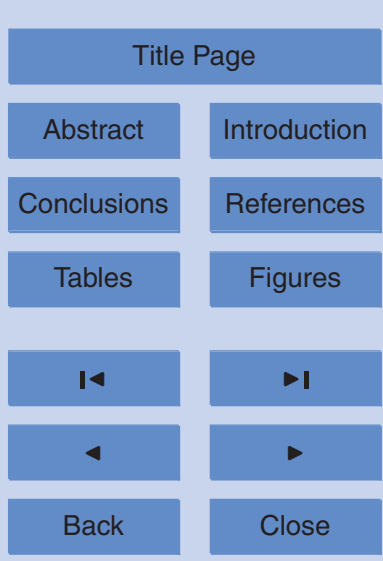

Full Screen / Esc

Printer-friendly Version

Interactive Discussion 


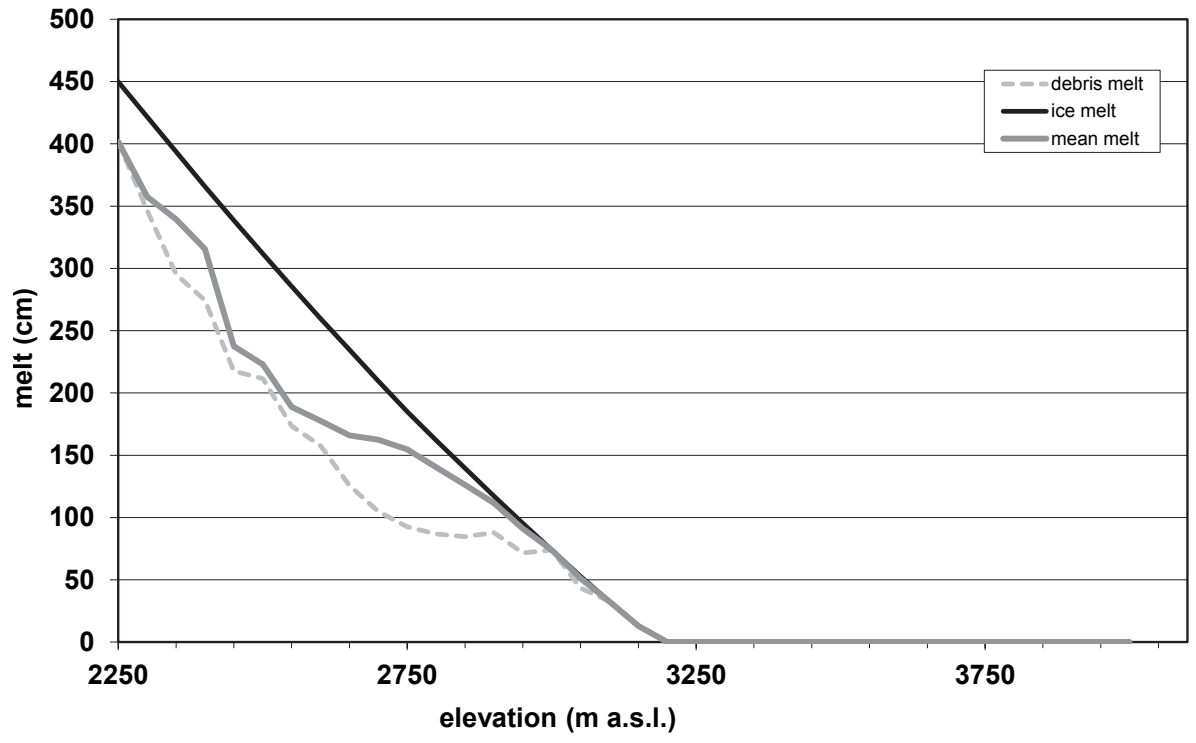

Fig. 8. Model results for simulating ice melt of all three Aktru glaciers for the year 2000.

5, 401-430, 2011

\section{Glacial debris cover and melt water production for glaciers \\ C. Mayer et al.}

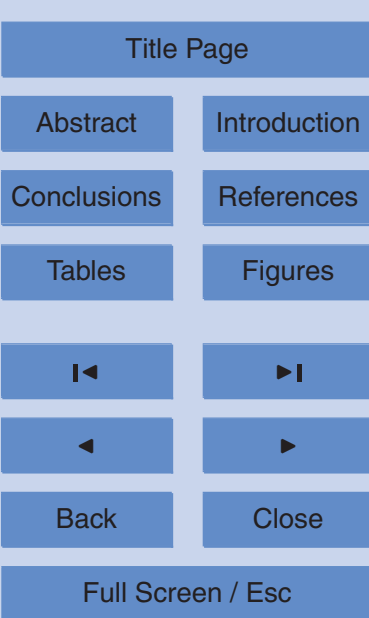

Printer-friendly Version

Interactive Discussion 